\title{
Trudne życie na wolności Korespondencja Karola Buczka z Gerardem Labudą z lat 1954-1956
}

\begin{abstract}
Zarys treści: Autor przedstawia korespondencję dwóch historyków, Karola Buczka i Gerarda Labudy, z lat 1954-1956. Listy te pisane były od momentu wyjścia K. Buczka z więzienia w 1954 r. aż do zawieszenia mu kary więzienia w połowie 1956 r. Pokazują one stan ducha krakowskiego historyka, jego myśli, niepewność co do przyszłości, a także próbę powrotu do życia naukowego.
\end{abstract}

\begin{abstract}
The author presents the correspondence of two historians, Karol Buczek and Gerard Labuda, from the years 1954-1956. The letters were written from the moment of Buczek's leaving prison in 1954 until his imprisonment was suspended in mid-1956. They show the state of mind of the historian from Cracow, his thoughts and uncertainly about his future, as well as an attempt at returning to scholarly life.
\end{abstract}

Słowa kluczowe: Karol Buczek, Gerard Labuda, korespondencja, historiografia XX w.

Keywords: Karol Buczek, Gerard Labuda, correspondence, $20^{\text {th }}$ century historiography

Korespondencja inteligencji polskiej XX w. od dawna cieszy się dużym zainteresowaniem, zarówno edytorów, jak i czytelników. W ogromnej większości wydaje się jednak listy pisarzy lub artystów. O wiele mniejszą popularnością cieszą się listy naukowców. Wydawano do tej pory jedynie nieliczne listy filozofów, polonistów lub socjologów ${ }^{1}$. Jeszcze mniej mamy edycji korespondencji dwudziestowiecznych historyków². Listy Karola Buczka do Gerarda Labudy są, na tle dotychczasowych

1 Przykładowo: H. B u c z yń s k a - G a rew i c z - J. G a r e w i c z, Listy. Warszawa, Paryż, Boston, t. I-II, wyd. H. Buczyńska-Garewicz, Warszawa 2015; S. C z a r n o w s k i, Listy do Henri Huberta i Marcela Maussa (1905-1937), wyd. K. Kończal, J. Wawrzyniak, Warszawa 2015; M. D a n i e le w i c z o w a - S. P i g o ń, Dialog korespondencyjny (19581968), wyd. C. Kłak, Rzeszów 1996; L. K oła k o w s k i - A. Wa l i c k i, Listy, 1957-2007, wyd. A. Walicki, H. Citko, Warszawa 2018; Intymny portret uczonych. Korespondencja Marii i Stanisława Ossowskich, wyd. E. Neyman, konsultacja M. Ofierska, Warszawa 2002.

2 Przykładowo: M. H o s z o w s k a, Szymon Askenazy i jego korespondencja z Ludwikiem Finklem, Rzeszów 2013; S. K i e n i e w i c z - H. W e r e s z y c k i, Korespondencja z lat 19471990, wyd. E. Orman, Kraków 2013; Listy Aleksandra Gieysztora (wybór), wyd. P. Węcowski, w: Aleksander Gieysztor. Człowiek i dzieło, Warszawa 2016, s. 347-583; Materiały do biografii Benedykta Zientary, opr. P. Węcowski, D. Zielińska, w: Benedykt Zientara (15 VI 
edycji, wyjątkowe. Powstały w pierwszych kilkunastu miesiącach po wyjściu tego pierwszego z więzienia, w którym spędził siedem lat. Listy dokumentują losy, ale głównie odczucia, emocje i myśli człowieka, który dopiero co wyszedł na wolność. Niewiele jest tego typu źródeł, pokazujących na bieżąco, a nie z perspektywy wielu lat, więzienne losy polskiej inteligencji po $1945 \mathrm{rr}^{3}$

Karol Buczek urodził się w 1902 r. w Kaszowie, wsi leżącej niedaleko Krakowa. Po skończeniu studiów historycznych na Wydziale Filozoficznym Uniwersytetu Jagiellońskiego został zatrudniony jako bibliotekarz w Bibliotece przy Muzeum Książąt Czartoryskich (1927 r.) ${ }^{4}$. W 1930 r. został kierownikiem (kustoszem) tej biblioteki. Od 1936 r., po uzyskaniu habilitacji, prowadził także wykłady na Uniwersytecie Jagiellońskim. Do 1939 r. opublikował ponad 80 artykułów, przyczynków i recenzji naukowych. Rozwijającą się karierę naukowca, bibliotekarza i archiwisty przerwała wojna. Po jej zakończeniu Buczek wrócił do pracy w Bibliotece Czartoryskich. Poza działalnością naukową i organizacyjną Buczek wiele czasu i serca poświęcał działalności politycznej. Od 1934 r. był członkiem Stronnictwa Ludowego. W czasie wojny działał w Ruchu Oporu Chłopskiego, m.in. redagując i wydając gazety ruchu ludowego. Po wojnie, w 1945 r., został redaktorem naczelnym tygodnika Piast, związanego z Polskim Stronnictwem Ludowym, był też przewodniczącym Zarządu Grodzkiego PSL w Krakowie. Ta właśnie działalność przyczyniła się do uwięzienia Karola Buczka we wrześniu 1946 r. Oficjalnym powodem aresztowania było gromadzenie i przekazywanie informacji zawierających tajemnicę państwową oraz chęć obalenia przemocą ustroju państwa. Zarzut ten miał, rzecz jasna, przykryć prawdziwe powody - walkę komunistów z opozycją, w tym z Mikołajczykowskim PSL-em.

W sierpniu 1947 r. Buczek, jako jeden z kilkunastu oskarżonych, stanął przed Wojskowym Sądem Rejonowym w Krakowie. Prokurator domagał się dla niego kary śmierci. Tak zwany proces krakowski zakończył się we wrześniu $1947 \mathrm{r}$. wydaniem aż ośmiu wyroków śmierci, z których trzy wykonano. Buczek został skazany na 15 lat więzienia oraz 5 lat utraty praw publicznych i obywatelskich ${ }^{5}$. Od razu po procesie, we wrześniu 1947 r., został przeniesiony z więzienia w Krakowie

1928 - 11 V 1983). Dorobek i miejsce w historiografii polskiej, Warszawa 2001; W. P o b ó g - M a l i n o w s k i - W. J ę d r z e j e w i c z, Listy 1945-1962, opr. S. M. Nowinowski, R. Stobiecki, Warszawa 2016; P. W ę c o w s k i, Przedwojenne listy Aleksandra i Ireny Gieysztorów do Marcelego Handelsmana (w druku); M. W i 11 a u m e, Listy Marcelego Handelsmana do Zygmunta Lubicz-Zaleskiego (1911-1939), Akta Towarzystwa Historyczno-Literackiego w Paryżu 2, 1993, s. 165-235; Z listów do Izy Bieżuńskiej-Małowist, wyd. K. Stebnicka, Przegląd Historyczny 87, 1996, s. 451-467.

3 Z. i K. M o c z a r s c y, „Życie tak nas głupio rozłącza”. Listy więzienne, 1946-1956, wyd. A. Machcewicz, Warszawa 2015.

${ }^{4}$ Karol Buczek (1902-1983). Człowiek i uczony, red. D. Karczewski, J. Maciejewski, Z. Zyglewski, Kraków-Bydgoszcz 2004. Zob. F. S i k or a, O życiu i działalności Karola Buczka, w: K. Buczek, Studia z dziejów ustroju społeczno-gospodarczego Polski piastowskiej, t. I, Kraków 2006, s. 15-36, oraz K. B u c z e k, Autobiografia mediewisty-polityka, wyd. J. Dużyk, Studia Historyczne 35, 1992, s. 401-413.

5 P. B i 1 i ń s k i, „Przypadek” Karola Buczka, Arcana 46-47, 2003, s. 96-105; F. M u s i a ł, Polityka czy sprawiedliwość. Wojskowy Sąd Rejonowy w Krakowie (1946-1955), Kraków 2005, s. 326-341. 
do Wronek, później zaś (w styczniu 1948 r.) do więzienia mokotowskiego w Warszawie. W czerwcu 1952 został znowu przeniesiony do Wronek, a w styczniu 1954 r. do Rawicza. Stamtąd, 14 XI 1954 r., Buczek został zwolniony w celu odbycia rocznej kuracji. W listopadzie 1955 r. udzielono mu przerwy w odbywaniu wyroku, tym razem na cztery miesiące. W marcu 1956 r. uzyskał następne odroczenie - na trzy miesiące. Przed ich upływem, w maju 1956 r., Wojskowy Sąd Garnizonowy w Krakowie zmniejszył wyrok do 10 lat pozbawienia wolności. Już jednak miesiąc później, 15 VI 1956 r., Rada Państwa zawiesiła wykonywanie reszty kary na dwa lata. W ten sposób, przynajmniej od strony prawnej, gehenna Karola Buczka dobiegła końca, choć rehabilitacja oskarżonych w procesie krakowskim została dokonana przez Sąd Najwyższy dopiero w sierpniu 1989 r.

Zarówno w czasie pobytu w więzieniu, jak i w czasie przerwy w odbywaniu kary, historyk słał do prezydenta Bolesława Bieruta oraz do prezydium Rady Państwa prośby o ułaskawienie ${ }^{6}$. Podania te są wstrząsającym świadectwem tych czasów, mimo że zgodnie z konwencją źródła, są one „suche” i musiały być pozbawione elementów emocjonalnych.

Do czasów więziennych Buczek wracał niekiedy zarówno w listach, jak i w pracach naukowych. W tych ostatnich nie pisał co prawda wyraźnie o więzieniu, lecz dla każdego czytelnika było jasne, o czym jest mowa ${ }^{7}$. Wypowiedzi te były jednak bardzo ogólnikowe, dlatego tak ważne wydają się listy pisane po opuszczeniu więzienia w Rawiczu. Pokazują one, jak trudno było K. Buczkowi funkcjonować w pierwszych kilkunastu miesiącach, kiedy przebywał na wolności, ale pod ciążącą presją konieczności bliskiego powrotu do więzienia. Listy te uzupełniają informacje o kolejach losu Buczka, m.in. prostują opinię, jakoby wrócił on w 1955 r. na jeden dzień do więzienia (list nr 6). Przede wszystkim jednak oddają ówczesny stan ducha krakowskiego badacza, jego myśli, obawy i niepewność co do przyszłości. Pokazują też próbę powrotu do dawnej profesji i do pisania prac naukowych. Mogą być także drobnym świadectwem funkcjonowania polskiego inteligenta (naukowca) w pierwszych miesiącach po wyjściu ze stalinowskiego więzienia.

Wydawane listy K. Buczka skierowane były do przyjaciela - Gerarda Labudy (1916-2010), wybitnego historyka, w późniejszym czasie m.in. dyrektora Instytutu Zachodniego, rektora Uniwersytetu im. Adama Mickiewicza w Poznaniu, sekretarza generalnego i prezesa Poznańskiego Towarzystwa Przyjaciół Nauk, wiceprezesa Polskiej Akademii Nauk, prezesa Polskiej Akademii Umiejętności, honorowego doktora sześciu uniwersytetów ${ }^{8}$. W czasie, z którego pochodzą listy, Labuda był profesorem nadzwyczajnym, kierownikiem Katedry Historii Polski w Instytucie Historii

${ }^{6}$ F. D ą b r o w s k i, Pięć listów Karola Buczka do władz komunistycznej Polski, Kwartalnik Historii Kultury Materialnej 56, 2008, nr 1, s. 91-107.

${ }^{7}$ Np. K. B u c z e k, O chłopach w Polsce piastowskiej, cz. I, Roczniki Historyczne 40, 1974, s. 51: „zaraz po powrocie do normalnego życia (pod sam koniec 1954 r.) zabrałem się z impetem do generalnej - - reinterpretacji źródeł do ustroju społeczno-ekonomicznego i politycznego Polski piastowskiej”.

${ }^{8}$ Naukowe dzieło Profesora Gerarda Labudy, red. J. Dobosz, Poznań 2006 (tu na s. 161282 bibliografia prac); Pro memoria. Gerard Labuda (1916-2010), wyd. J. Borzyszkowski, Gdańsk-Wejherowo 2011; J. S t r z e 1 c z y k, Gerard Labuda 1916-2010, Roczniki Historyczne 76, 2010, s. 9-26 (z uzupełnieniami do bibliografii). 
Uniwersytetu Poznańskiego, kierownikiem Zakładu Historii Pomorza w Instytucie Historii PAN, a także wicedyrektorem Instytutu Zachodniego (od 1955 r.).

Listy znajdują się w spuściźnie poznańskiego historyka w Muzeum Piśmiennictwa i Muzyki Kaszubsko-Pomorskiej w Wejherowie (dalej: MPiMKP). Najstarszy z listów pisany był zaledwie pięć dni po opuszczeniu przez K. Buczka więzienia w Rawiczu. Trzy ostatnie, niestety uszkodzone (oderwane górne brzegi) i pozbawione daty, napisane zostały - jak świadczy ich treść - wkrótce po 15 VI 1956 r. i po otrzymaniu przez krakowskiego historyka informacji o ułaskawieniu (nr 1-9). W spuściźnie Labudy nie zachowały się wcześniejsze listy Buczka z więzienia. Czy takie były - nie wiadomo. Być może odpowiedzi na to pytanie udzieli kwerenda w zbiorach Instytut Pamięci Narodowej. Z interesującego mnie okresu udało się natomiast odnaleźć tylko jeden list pisany do Buczka przez Labudę (nr 10). Znajduje się on w spuściźnie krakowskiego historyka w Bibliotece Naukowej Polskiej Akademii Umiejętności i Polskiej Akademii Nauk w Krakowie. Niestety, nie ma w niej wcześniejszych listów, które na pewno istniały.

Nie wiadomo, od kiedy datuje się znajomość i przyjaźń Buczka z Labudą. Już pierwszy z listów, a także kolejne, pokazuje bardzo bliską zażyłość obu korespondentów. Świadczy o tym choćby formuła, jakiej używał Buczek: „Kochany Gerardzie”. Użycie takiej formy, i to w czasach, kiedy nawet rówieśnicy późno przechodzili ze sobą na „ty”, wskazuje na bardzo bliskie relacje. Świadczy o tym także informacja, że Labudowie przesyłali Buczkowi do więzienia paczki, a żona Buczka, Jadwiga, jeżdżąc do uwięzionego męża, nocowała u Labudów ${ }^{9}$. Bliskie relacje między obydwoma historykami musiały więc być nawiązane jeszcze przed aresztowaniem krakowskiego badacza we wrześniu 1946 r. Wydaje się, że nastąpiło to już w 1939 r. W momencie rozpoczęcia wojny Labuda - student historii Uniwersytetu Poznańskiego - musiał uciekać z Poznania. W grudniu 1939 r. przyjechał do Krakowa, gdzie chodził na zajęcia prowadzone przez Zofię Kozłowską-Budkową. Mieszkał w Krakowie dwa miesiące, kiedy to opuścił miasto i schronił się w majątku Wielopolskich w Chrobrzu ${ }^{10}$. W Krakowie Labuda mieszkał (nie wiadomo, jak długo) właśnie u Buczków. Jak się wydaje, wtedy zawiązały się bliskie i przyjacielskie stosunki między historykami, podtrzymywane najpewniej korespondencyjnie w czasie wojny, jak i w pierwszych miesiącach po jej zakończeniu.

Edycja została przygotowana zgodnie z projektem instrukcji edytorskiej Ireneusza Ihnatowicza $^{11}$, z pewnymi zmianami. Interpunkcję i pisownię listów zmodernizowano

9 W jednym z późniejszych listów (1967) Buczek pisał do Labudy, że żona ,wspomina często odwiedziny w Waszym Domu we wronkowskim okresie mojego procesu historycznego" (Wejherowo, MPiMKP, zbiory G. Labudy, karton 20, teczka 2, nlb.).

${ }_{10}$ W 1964 r. G. Labuda tak pisał Józefowi Mitkowskiemu o swoim przyjeździe do Krakowa: „Do Krakowa przyjechałem koło 10 grudnia 1939 r., ponieważ otrzymałem wiadomość od prof. Wojtkowskiego (obecnie w Lublinie), że od 11 XI będzie w Krakowie otwarty UJ. Nie wiedziałem oczywiście na Pomorzu, jak się skończyło to »otwarcie«. Dowiedziałem się o tym dopiero w Krakowie. W Krakowie zastałem tylko doc. dr. Karola Buczka, który ocalał, ponieważ nie był na »otwarciu«. On skierował mnie do p. Budkowej. W posiedzeniach brałem udział przez cały grudzień i styczeń. Już w lutym musiałem uciekać z Krakowa, bo gestapo było na moim tropie (wskutek współpracy przy książce Kisielewskiego, Ziemia gromadzi prochy)" (tamże, karton 7, nlb.).

${ }^{11}$ I. I h n a to wic z, Projekt instrukcji wydawniczej dla źródeł historycznych XIX i początku XX w., Studia Źródłoznawcze 7, 1962, s. 99-124. 
i poprawiono, zachowując jednak kilka osobliwości językowych i gramatycznych. Cudzysłowy i średniki w listach pochodzą od K. Buczka. Rozwijam brzmienie dat, instytucji i nazwisk, które w listach pisane są w formie skróconej, np. sformułowania „55”, „Inst.Zach.”, „Leśn.”, rozwiązano jako „1955”, „Instytut Zachodni”, „Leśnodorski”. Zachowano układ listów, nie zmieniając alineacji tekstu.

Za zgodę na kwerendę w spuściźnie poznańskiego historyka w Wejherowie oraz za zgodę na edycję listów bardzo dziękuję prof. Adamowi Labudzie i Rodzinie Gerarda Labudy. Bardzo także dziękuję pani dr Elżbiecie Knapek za pomoc w dotarciu do listu G. Labudy do K. Buczka.

\section{TEKSTY ŹRÓDŁOWE}

\section{1}

Or.: Wejherowo, MPiMKP, zbiory G. Labudy, skrzynia 32, teczka 7, t. 2, nlb. (rękopis).

Kraków, 19 listopada 1954

Kochany Gerardzie,

w niedzielę [14 XI] opuściłem Rawicz, wydelegowany na zdrowotny, roczny urlop i odetchnąwszy trochę po rozkoszach z górą ośmioletnich wywczasów w różnych internatach wychowawczych, łapię za pióro, pragnąc choć tą drogą i w ten niezbyt udany sposób wyrazić serdeczną i gorącą podziękę Drogim Państwu za tyle Wiśce ${ }^{1}$ i mnie okazanej, naprawdę przyjacielskiej, życzliwości i pomocy. Bądź też łaskaw wyrazić specjalną wdzięczność i podziękowanie swojej Mamusi² za wspaniałe pończochy własnej roboty, które oddały mi ogromną przysługę w ubiegłym i bieżącym roku. Szczerze Ci też gratuluję wspaniałych sukcesów naukowych, znanych mi zresztą, jak na razie, tylko z relacji dziennikarskich i żoninych, a przede wszystkim 4 nie mniej wspaniałych synów-łobuzów i córki faworytki ${ }^{3}$. Martwię się tylko, i to szczerze, tym, że pracujesz nad miarę i ponad siły, których Ci już podobno zaczyna brakować, nie chcę Ci jednak, Mój Drogi, udzielać tanich rad, bo te nie raz i nie dwa mnie samego wyprowadzały z nerw.

Sam zresztą bardzo rady potrzebuję i choć to nieładnie, a może i niedobrze z mej strony, chcę Cię o radę i - w miarę możności - o pomoc prosić. Sytuacja moja mimo bezsprzecznej poprawy - pozostaje nadal trudną i skomplikowaną. Rzecz leży w tym, że przez ten rok muszę 1-o - z czegoś żyć, a 2-o - postarać się o pozostanie na wolności po jego upływie. Pewnie by mi dano jakąś posadę biurową, nie sądzę jednak, bym mógł przy tym podreperować swoje zdrowie, a nawet utrzymać je w obecnym stanie, no i zabezpieczyć sobie pobyt na świeżym powietrzu na dalsze lata. Z tego też względu bardziej celowym i sensownym wydaje mi się, będzie zabrać się do orki na niwie nauki, co zresztą robiłem już w Mokotowie w latach 1947-1951. Dysponując nadal ograniczonymi środkami (źródła i literatura), zabrałem się tam zrazu, w ogromnej mierze pod wrażeniem Twoich „Studiów”4 oraz z irytacji nad pracami Widajewicza ${ }^{5}$, do zagadnień IX-X-wiecznych i nawet to i owo na tym polu ciekawego udało mi się wyszperać, zwłaszcza w odniesieniu do stosunków polsko-czesko-niemieckich oraz interpretacji relacji Ibrahima i (nie śmiej się!) Dagome iudex, tak że będę się starał o tych 2 źródłach jeszcze koniecznie napisać, bez obawy 
narażenia się na śmieszność nauki na nową „hipotezę”, a czytelników na irytację. Mam też ciekawy szczegół do interpretacji dokumentu fundacyjnego biskupstwa bamberskiego w związku z Twoimi Łużycami ${ }^{6}$, wiem mianowicie na pewno, co tam było interpolacją ,Łużyc”.

Z tym wszystkim, po jakimś roku, porzuciłem wspomniany temat i stopniowo przeszedłem do opracowywania swoich „Studiów nad strukturą ekonomiczną i społeczną Polski wczesnofeudalnej", tzn. do przerobienia od nowa albo od początku wszystkich bez wyjątku, bardziej - mniej - lub wcale nietykanych problemów na przestrzeni „od początku” do przełomu wieków XIII i XIV, przy czym, operując często-gęsto retrogresją, sięgać musiałem, tak gdy chodzi o źródła, jak i problematykę, do końca średniowiecza, a nawet i do wieku XVI. Biorąc pod uwagę fakt, że z wydawnictw źródłowych korzystać mogłem w minimalnym stopniu (moje własne wyszły z domu na przymusową, choć czasową tylko emigrację $)$, a i z dostępem do literatury było bardzo ciężko i rozmaicie (przypuszczam, że wiesz coś o tym od Wiśki), można by mnie uznać za wariata, i to kiepskiego, zwłaszcza że porywanie się na pracę obliczaną na trzy wielkie tomy, a więc i na całe lata, było jak najbardziej sprzeczne z moimi doraźnymi interesami ${ }^{8}$. Niemniej jednak ciekawość i żyłka naukowa we mnie zwyciężyła, zacząwszy robotę od chęci wyrobienia sobie ogólnego poglądu na sprawę i zorientowawszy się na 1, 2, 10 i 50 przykładach o prawie absolutnej bezwartościowości dotychczasowego w tym zakresie dorobku (pewnie zaczniesz bezwiednie robić palcem kółka na czole i myśleć, że urlop dostałem zbyt późno, by można jeszcze coś uratować), zakopywałem się w robocie coraz głębiej i głębiej, rozszerzałem sobie tematykę z miesiąca na miesiąc. Korzystałem w całej pełni ze swojego bojowego nastawienia w stosunku do wszystkich autorytetów i najbardziej murowanych teorii oraz z tego, że wreszcie miałem czas każdy szczegół gruntownie i wszechstronnie przemyśleć, a robiąc pełny całokształt, musiałem siłą rzeczy wszystko ze sobą uzgodnić we wzajemnym stosunku, w stopniu rozwoju, w czasie i przestrzeni. I choć dysponowałem tylko materiałem, którego mi dostarczyły moje ofiary, przecież udało mi się uzyskać obraz dość pełny, jasny i zwarty oraz wyniki ważne nie tylko w skali krajowej, dzięki bowiem specyfice naszego rozwoju i źródeł Polska może służyć za kapitalny wprost przykład tego, jak rozwijał się proces przejścia od ustroju rodowo-plemiennego do stanowego państwa, odbywający się w głównej mierze właśnie na przestrzeni X do XIV w.

Może Cię będzie śmieszyć ta autoreklama, ale myślę, że może kiedyś uda mi się przekonać Cię, choć prędko to nie nastąpi, bo rzecz nawet po odrzuceniu, a raczej silnej kondensacji spraw mniej spornych i istotnych, wymagać będzie jeszcze wiele pracy. Wątpię też bym w ciągu tego urlopowego roku mógł się zabrać do tego tematu, raczej bowiem wypadnie mi obrobić i puścić w kurs parę detali, które bez szkody dla sprawy mogą być wyrwane z całości. Po pierwsze bowiem muszę zarobić coś na życie, a po drugie czymś się wykazać na koniec mego urlopu. Mógłbym oczywiście wziąć się do początków kartografii polskiej albo do kartografii doby stanisławowskiej (Perthées) ${ }^{9}$, sądzę jednak, że lepiej to będzie zrobić w opracowaniu całości dziejów tej dyscypliny w Polsce ${ }^{10}$, wątpię też, by mi się kalkulowało kończyć Macieja Miechowitę lub robić lustrację dróg w II połowie XVI w. ${ }^{11}$, gdyż przy obecnym stanie środków pomocniczych roboty te mogą mnie kosztować zbyt wiele czasu i trudu. 
W mojej sytuacji, rad nie rad, muszę iść na „łatwiznę” i dlatego taki sobie właśnie wypisałem panegiryk, żeby Cię, Mój Kochany, zorientować co do moich możliwości na wypadek, gdybyś chciał i mógł mi coś niecoś pomóc. Poza tym sądzę, że ciekaw będziesz tego, com robił i zrobił w ciągu naszej rozłąki. Nie twierdzę bynajmniej, że wynoszę z niej same plusy, bo choć wiele się nauczyłem i zrozumiałem na tych kilku „uniwersytetach”, choć zbliżyłem się do ideału filozofa, pozbywając się mnóstwa nawyków, nerwowości itd., to jednak masę też zapomniałem w tym czasie, no i straciłem sporo czasu i sił. Cieszę się oczywiście z wyjścia, przede wszystkim ze względu na Wiśkę, którą znalazłem w stanie o wiele gorszym, niż mogłem się spodziewać, wprost u samego kresu wytrzymałości fizycznej i nerwowej. Nie wątpię jednak, że mimo ciężkich nadal warunków szybko się z tego otrząśnie, a i ja pewnie wnet przyjdę do formy, zwłaszcza że już teraz ponoć jestem w nie najgorszej.

Kończę, wyrażając nadzieję, że coś mi odpiszesz i nie odmówisz przysłania swoich prac z okresu po 1946 r., ściskam Cię zatem mocno, dołączając najpiękniejsze ukłony i ucałowania rączek dla Pani ${ }^{12}$ oraz mnóstwo serdeczności dla nieznanych mi niestety Twoich pociech, no i raz jeszcze dziękuję za tyle okazanej Wiśce i mnie życzliwości, serca i pomocy.

Wasz szczerze oddany

Karol

[P.S.] Zapomniałem dodać do kompletu moje możliwości w zakresie kartografii historycznej (Atlas), również w odniesieniu do rekonstrukcji krajobrazu wczesnohistorycznego.

${ }^{1}$ Jadwiga Buczek z Czajewiczów (1905-1971), od 1924 r. żona K. Buczka. ${ }^{2}$ Anastazja Labuda z Baranowskich (1881-1974). ${ }^{3}$ Aleksander (ur. 1944), Iwo (ur. 1945), Adam (ur. 1946), Damian (ur. 1949), Anastazja (ur. 1953) - dzieci Gerarda i Alberty Labudów. ${ }^{4}$ G. Labuda, Studia nad początkami państwa polskiego, Poznań 1946. 5 Józef Widajewicz (1889-1954), historyk, pracownik Uniwersytetu Poznańskiego (1937-1939) i Uniwersytetu Jagiellońskiego (1945-1954). Chodzi najpewniej o publikacje: Państwo Wiślan, Kraków 1947, oraz Poczatki Polski, Wrocław-Warszawa 1948. ${ }^{6}$ G. Labuda, Studia z dziejów Stowiańszczyzny Zachodniej, II. Łużyce w dokumencie biskupstwa brandenburskiego z r. 948, Slavia Occidentalis 19, 1948, s. 120-139. ${ }^{7}$ W 1947 r. K. Buczek zostat skazany także na przepadek mienia. Jego książki zostały skonfiskowane przez Urząd Bezpieczeństwa. ${ }^{8}$ O planowanym, trzytomowym, dziele pt. Studia nad struktura społeczna i ekonomiczna Polski wczesnofeudalnej, Buczek mówit już w 1952 r., informując, że pracuje nad tym od 1948 r. „, Trylogia” miała obejmować książki: Targi i miasta na prawie polskim (wyd.: Wroctaw-Kraków 1964), Prawo rycerskie i organizacja stanu szlacheckiego i Poczatkowe dzieje klasy chłopskiej w Polsce. ${ }^{9}$ Mapy Karola Perthéesa, kartografa Stanisława Augusta, byty tematem pracy doktorskiej K. Buczka z 1927 r. Monografię tego geografa Buczek pisat wiele lat, nie zdażyt jej jednak opracować. Została ona opublikowana dopiero w 2003 r.: K. Buczek, Kartograf króla Stanisława Augusta. Życie i dzieta (przypisami opatrzyt i opracowat do druku H. Rutkowski), w: Karol Perthées (1739-1815) fizjograf Pierwszej Rzeczypospolitej, 2003, s. 21-120. ${ }^{10}$ K. Buczek, Dzieje kartografii polskiej od XV do XVIII w. Zarys analityczno-syntetyczny, Wrocław-Kraków 1963. ${ }^{11}$ Ostatecznie wydała ja B. Wyrozumska: Lustracja dróg województwa krakowskiego z r. 1570, wyd. B. Wyrozumska, Wrocław 1971 (K. Buczek napisat tam ,, Wstęp historyczny”, s. V-XVIII). ${ }^{12}$ Alberta Labuda z domu Wielopolska (1917-1999), romanistka, pracownik UAM w Poznaniu (1946-1951, 1957-1977), żona G. Labudy od 1943 r. 
Or.: Wejherowo, MPiMKP, zbiory G. Labudy, skrzynia 32, teczka 7, t. 2, nlb. (rękopis).

Kraków, 9 grudnia 1954

Kochany Gerardzie,

serdecznie Ci dziękuję za arcymiły list i z miejsca nań odpisuję, chcąc Ci zobrazować choć z grubsza moją sytuację i moje myśli. Jeśli chodzi o sprawę mojego urlopu, to dość autorytatywny czynnik stwierdza, że „nie powinienem żyć widmem powrotu do więzienia", i choć nie należę do optymistów, sądzę, że tak jest istotnie, z tym oczywiście, że w dzisiejszych czasach na nic z pewnością liczyć nie mogę. Najgorsze jest to, że trudno mi w tej sytuacji coś planować sub specie aeternitatis, jakbym powinien, i że nie wiem, czy zdołam się gdzieś uwiesić na możliwych warunkach, $\mathrm{i}$ to $\mathrm{z}$ widokami na dalszą przyszłość. Takie zaś zawieszenie jest dla mnie niezbędne, gdyż 1-o: nie mogę w moim położeniu bawić się w jakiegoś „Privatgelehrter'a", a 2-o: muszę coś zarobić, bo moja żona nie potrafi mię utrzymać ze swej pensji, zwłaszcza, że muszę sobie reperować zdrowie, zęby (zostały mi 4), garderobę itd. Wolałbym oczywiście nie łapać za pierwsze lepsze engagement, lecz urządzić się plus minus na stałe, przy czym jednak zdaję sobie doskonale sprawę z trudności w uzyskaniu takowego oraz z wątpliwej jego stałości. Nie wiem bowiem, co o tym wszystkim myślą moi przełożeni z byłego $\mathrm{MBP}^{1}$; nb. Arnold ${ }^{2}$ nie odpisał mi do dzisiaj na mój dziękczynno-komendacyjny list, a Manteuffel ${ }^{3}$ tylko pokwitował odbiór mojego zgłoszenia.

Rozejrzawszy się z grubsza w ogólnej sytuacji i w literaturze, straciłem dużo $\mathrm{z}$ początkowego rozmachu. Po pierwsze bowiem fatalne warunki mieszkaniowe uniemożliwiają mi pracę $\mathrm{w}$ domu i stworzenie sobie choćby namiastki warsztatu naukowego; nie da się jak na razie odblokować moich książek, a bez nich wątpię, czy potrafię uruchomić robotę $\mathrm{w}$ dziedzinie historii karto- i geografii (nasze biblioteki są strasznie ubogie pod tym względem). Po wtóre: szybko odczułem potężne braki w zakresie znajomości nowszej zwłaszcza i pozapolskiej literatury, wynikłe z długoletniego braku kontaktu z pracą naukową, czy nawet w ogóle z książką. Po trzecie widzę, że z moimi „studiami” społeczno-ustrojowymi nad X-XIII w. będę mógł wystąpić wtedy dopiero, gdy będą gotowe do publikacji, nazbyt się bowiem różnią od aktualnie oficjalnych na te czasy poglądów. Choć zatem zgadzam się z Tobą najzupełniej, że powinienem zabrać się do jakiejś większej i uczciwej roboty, to w rezultacie nie bardzo wiem - do czego. Przedwczoraj, odpisując Jadzi K. ${ }^{4}$, prosiłem ją, by wysondowała Gieysztora ${ }^{5}$ co do tematu „Badania nad historią osadnictwa ziem polskich" (problematyka, metodologia, krytyka dorobku, plany na przyszłość itp.), gdyż miałbym tu to i owo nowego i ciekawego do powiedzenia. Nie udało mi się jeszcze niestety przeczytać tego, coś Ty na ten temat napisał. Myślę, że dostanę to teraz razem z całym dorobkiem do 1947 (Samona ${ }^{6}$ nie wyłączając), przy sposobności zaś strasznie bym Cię prosił o ewentualne zakupienie dla mnie (forsę zaraz zwrócę) Nowackiego: Księgę uposażeń diecezji poznańskiej, no i innych źródeł oraz opracowań poznańskich z mojego zakresu.

Z mniejszych rzeczy mógłbym napisać dość szybko o łagiewnikach (ustalam, że są to książęcy piwowarzy i miodosytnicy) $)^{8}$, o Dagome iudex ${ }^{9}$, a ewentualnie też 
o narzazie (na 102\% jest to danina „odpłatna” za korzystanie z lasów do wypasu świń) ${ }^{10}$ i o polskim źródle polskiej relacji Ibrahima ${ }^{11}$. Dla IHKM ${ }^{12}$ miałbym jeszcze rozprawkę o lustracji dróg z II połowy XVI w., bardzo ciekawą i szczegółową, choć trochę fragmentaryczną lustrację dróg województwa krakowskiego. Nie myśl tylko, że chcę to wszystko zaraz pisać i publikować, chodzi mi, żebyś wiedział o mnie wszystko. Nb. Łodyński ${ }^{13}$ i Olszewicz ${ }^{14}$ bardzo mnie ciągną do kartografii, na razie jednak chciałbym wiedzieć, jak zareagują historycy na moje odżycie.

Jakkolwiek strasznie bym chciał uściskać Cię materialnie, a nie tylko idealnie, no i nagadać się z Tobą do syta, to jednak uważam Twój projekt przyjazdu do mnie za zbytek. Sądzę, że i listownie się dogadamy czegoś mądrego, dobrze by tylko było, gdybyś się jakoś dowiedział, co o mnie myślą czynniki decydujące o kadrach historyczno-geograficznych. Ale widzę, że Cię obarczam coraz to nowymi perangariami, zatem szybko kończę, całując Cię i ściskając mocno. Od Żony wiele serdeczności dla Obojga Państwa, a ja - po krakowsku - całuję rączki Pani

Karol

${ }^{1}$ Ministerstwo Bezpieczeństwa Publicznego. ${ }^{2}$ Stanisław Arnold (1895-1973), historyk, pracownik UW (1921-1966), Instytutu Historii PAN (1953-1965) i Wyższej Szkoty Partyjnej przy KC PZPR (1948-1966), dyrektor Departamentu Szkół Wyższych i Nauki Ministerstwa Oświaty (1945-1947). Na wniosek MBP S. Arnold oceniat, bardzo pozytywnie, walory naukowe Buczka, a także rozprawe o ksztaltowaniu się państwa polskiego $w$ X-XI w., która historyk napisat $w$ więzieniu. ${ }^{3}$ Tadeusz Manteuffel (1902-1970), historyk, pracownik Instytutu Historycznego UW (1930-1968, kierownik 1945-1955) i Instytutu Historii PAN (dyrektor 1953-1970). ${ }^{4}$ Jadwiga Karwasińska (1900-1986), historyk, wydawca źródet, pracownik Instytutu Historycznego UW (1930-39), Archiwum Głównego Akt Dawnych (1924-1951), Instytutu Historii Kultury Materialnej PAN (1954-1956), Instytutu Historii PAN (1957-1972). ${ }^{5}$ Aleksander Gieysztor (1916-1999), historyk, pracownik Instytutu Historycznego UW (1945-1986, dyrektor 1955-1975), Instytutu Historii PAN (1953-1968), dyrektor Zamku Królewskiego w Warszawie (1980-1991), przewodniczacy Międzynarodowego Komitetu Nauk Historycznych (19801985), prezes PAN. ${ }^{6}$ G. Labuda, Pierwsze państwo słowiańskie. Państwo Samona, Poznań 1949. ${ }^{7}$ Księga uposażenia diecezji poznańskiej z roku 1510, wyd. J. Nowacki, Poznań 1950. ${ }^{8}$ K. Buczek, Łagiewniki, Język Polski 36, 1956, z. 4, s. 245-257. ${ }^{9}$ Tenże, Zagadnienie wiarygodności regestu „Dagome iudex”, Sprawozdania z Posiedzeń Komisji PAN, Oddział w Krakowie, styczeń-czerwiec 1958, s. 21-23; tenże, Zagadnienie wiarygodności regestu „Dagome iudex”, Studia Źródłoznawcze 10, 1965, s. 117-139. ${ }^{10}$ Tenże, O narzazie, Studia Historyczne 14, 1971, s. 321-365. "II Tenże, Zagadnienie wiarygodności dwu relacji o poczatkowych dziejach państwa polskiego, w: Prace z dziejów Polski feudalnej ofiarowane R. Grodeckiemu w 70. rocznice urodzin, Warszawa 1960, s. 45-70. ${ }^{12}$ Instytut Historii Kultury Materialnej. ${ }^{13}$ Marian Lodyński (1884-1972), historyk, bibliotekarz, wicedyrektor Biblioteki Narodowej, kierownik prac dotyczących centralnego katalogu zbiorów kartograficznych w Instytucie Geografii PAN (1954-1968). ${ }^{14}$ Bolestaw Olszewicz (1893-1972), historyk geografii i kartografii, bibliotekarz, wykładowca Uniwersytetu Jagiellońskiego i Uniwersytetu Wrocławskiego. 
Or.: Wejherowo, MPiMKP, zbiory G. Labudy, karton 18, teczka 1, nlb. (rękopis).

Kochany Gerardzie,

Kraków, 21 maja 1955

wybacz, że Ci od razu nie podziękowałem za Nowackiego, Księgę uposażeń i za Twoją odbitkę, ale ciągle myślałem, że - zgodnie z zapowiedzią - zjedziesz na studia do Biblioteki Czartoryskich. Teraz maj dobiega końca, więc widzę, że Twoje plany uległy zmianie, bo nie słyszę, żebyś miał jakieś komplikacje ze zdrowiem. Choć zatem mocno spóźniony, przesyłam - wierz mi - nie zdawkowe, serdeczne podziękowania za wyżej wymienione książki, a zarazem chcę Cię prosić, o ile Ci to nie sprawi zbyt wielkiego kłopotu, o zamówienie dla mnie w Instytucie Zachodnim kroniki Thietmara ${ }^{1}$, której tu w Krakowie nie mogę dostać. Niech mi przyślą za zaliczeniem pocztowym, względnie zapłać im z miejsca, o ile udało Ci się sprzedać streptomycynę ${ }^{2}$. Jak widzisz, nie mogę wyleczyć się z manii gromadzenia książek, tym bardziej u mnie karygodnej, że ciągle nie wiem, czy te książki mi się na coś przydadzą. Jak na razie bowiem moje sprawy stoją ciągle w miejscu, a ja od czasu do czasu wykonuje tylko jakieś pomniejsze zleconka, przeważnie wewnętrzne recen$\mathrm{zje}^{3}$, tyle tylko, że nie jestem w 100\% na utrzymaniu Żony, czasem nawet zarabiając więcej niż Ona na miesiąc. Jak to długo będzie tak trwało, nie wiem, w najgorszym razie jeszcze pół roku, może jednak coś się wyklaruje wcześniej. Nie wiem niestety, co słychać z moją recenzją podręcznika; nie wątpię, że ją czytałeś już jako bliżej zainteresowany ${ }^{4}$. Ciekaw byłbym Twego zdania, ale widzę, że nikt nie chce farby puścić, być może skazano ją na to, by być totgeschwiegen. Byłem zresztą na to i na gorsze jeszcze rzeczy przygotowany $\mathrm{z}$ góry, więc się tym nie przejmuję, choć nie przeczę, że ciekawość mnie korci od czasu do czasu. Ostatecznie bowiem w pracę, której streszczeniem jest inkryminowany elaborat, włożyłem moc pracy i zdrowia.

Nie chcę Ci jednak zabierać za wiele czasu swoim ględzeniem, zatem kończę, łącząc od Wiśki i siebie dla Obojga Państwa i Waszej Czeredki moc najserdeczniejszych pozdrowień i wyrazów. Całuję Cię i ściskam prawicę

Karol

${ }^{1}$ Kronika Thietmara, wyd. M. Z. Jedlicki, Poznań 1953. ${ }^{2}$ Streptomycyna-lek należacy do grupy antybiotyków. Ówcześnie stosowany powszechnie, obecnie jedynie w leczeniu gruźlicy. ${ }^{3}$ Jak informowat K. Buczek w podaniu o ułaskawienie skierowanym do Rady Państwa 16 XI 1955 r., od czasu wyjścia z więzienia napisat sześć recenzji wewnętrznych na zlecenia redakcji Kwartalnika Historii Kultury Materialnej, Przegladu Historycznego oraz Instytutu Historii PAN. ${ }^{4}$ W grudniu 1954 r. dyrekcja IH PAN zamówiła u K. Buczka recenzję wewnętrzna trzech pierwszych części Historii Polski, przygotowywanej w Instytucie Historii PAN pod red. H. Łowmiańskiego. Jednym z autorów byt G. Labuda. K. Buczek ukończyt pisanie recenzji w lutym 1955 r. Jej tekst nie jest znany. 
Or.: Wejherowo, MPiMKP, zbiory G. Labudy, karton 18, teczka 1, nlb. (rękopis).

Kraków, 23 czerwca 1955

Kochany Gerardzie,

bardzo Ci dziękuję za miły list i obietnicę wystarania się o Thietmara, a zarazem przepraszam, że Cię obarczyłem tym zadaniem, co prawda nie wiedząc, że książki tej nie ma już na składzie w Instytucie Zachodnim. Ogromnie się ucieszyłem tym, że recenzja „Podręcznika” tak Ci się spodobała, bo oczywiście Twoja opinia w tej materii jest jak najbardziej miarodajna. Nie dziw się, że byłem jej ciekawy, ale przecież chodzi tu o wcale niemały przewrót w naszej i nie tylko naszej historiografii, i to przez kogo robiony. Zdając sobie też sprawę ze słuszności Twoich rad, nie mogłem jednak napisać tej recenzji inaczej, bo bym nie potrafił i dziś, gdybym się znalazł w analogicznej sytuacji, inaczej bym nie postąpił, bo ostatecznie sumienie naukowe mam tylko jedno. Z faktu, że nawet autorom „Podręcznika” nie rozesłano do wglądu recenzji, nie wróżę po niej nic dobrego dla siebie, niemniej jednak coś z tego chyba wyjdzie, bo z faktami długo walczyć się przecież nie da, zwłaszcza w nauce. $\mathrm{Nb}$. przysłano mi z Instytutu Historii PAN przed miesiącem z górą do podpisania formularz umowy na tęż recenzję oraz rachunek na 500 zł honorarium (z PWN swoje dostałem), którego zresztą do dziś nie otrzymałem. Bo umowę i rachunek podpisałem, nie bardzo „kapując”, o co tu chodzi i po co to wszystko, podobnoć jednak darowanemu koniowi nie trzeba patrzeć w zęby. Napisałem w tej sprawie do Manteuffla (figurował jako zleceniodawca, podpisany był Leśnodorski ${ }^{1}$ ), ale mi nie odpisał; może zawigujesz [sic!] przy okazji i dowiesz się, co ta extrahojność oznacza?

Gorzej, że na mój pisany przed paru tygodniami list nie odpisuje nic Jadźka K. W swoim czasie ofiarowała się uzupełnić luki w mej bibliotece, więc prosiłem Ją o skombinowanie dla mnie quolibet modo niepuszczonego do handlu numeru (bodaj 3) Kwartalnika Historii Kultury Materialnej za ubiegły rok, a poza tym numery 1-2 Kwartalnika Historycznego z r. 1948 (t. 56) i numeru 3 z r. 1953 (t. 60), których mi brakuje do kompletu. Zależy mi zwłaszcza na Kwartalniku H.K.M., bo chciałbym mieć koniecznie całość. Nie wiem, czy nie dostała mego listu, czy może zrozumiała, że chciałbym mieć te rzeczy gratis i franco, czy też ma już dość naszej odwiecznej przyjaźni. W każdym razie milczenie to mnie bardzo niepokoi, a boję się narzucać się Jej, jeśli istotnie ma miejsce trzecia z wymienionych ewentualności, jeśli zatem będziesz w Warszawie lub będziesz do Niej pisał, to zagadnij Ją o tę sprawę.

Bardzo mi przykro, że Cię, Mój Drogi, obarczam coraz to nowymi angariami i perangariami, ale ja jeszcze się jakoś nie wżyłem w nowe warunki, a zwłaszcza trudno mi się zżyć - choćby i z powrotem - z ludźmi, ciągle zresztą potrzebuję pomocy, rady czy informacji, a wiem, że każdy ma tysiące własnych spraw i kłopotów. Zwłaszcza zaś Ty, przy mnóstwie swoich zajęć i kiepskim nadal zdrowiu. Sądzę jednak, że przez wakacje będziesz chyba dokumentnie wypoczywał na łonie rodziny i jakiejś pięknej przyrody.

Jeśli chodzi o mnie, to też niewielki ze mnie Herkules. Na oko biorąc, nic mi dalej nie brakuje i dobrze nawet wyglądam, ale słaby jestem bardzo i łatwo się męczę. Toteż i robota idzie mi bardzo niesporo, zwłaszcza, że dużo czasu pochłaniają mi zajęcia 
gospodarskie, od których - wobec braku forsy - nie sposób się wymigać. Nie mając żadnego zamówienia, siadłem do pisania swoich „łagiewników”. Niestety w „,praniu” okazało się, że chcąc zrobić rzecz porządnie, trzeba napisać pracę o ludności służebnej w ogóle, co też robię ${ }^{2}$, wyręczając po części Kolańczykaª Skkoniły mię do tego również bzdury, które popisał na ten temat Tymieniecki w ostatnim tomie „Studiów Wczesnohistorycznych"4 [recte: Wczesnośredniowiecznych]. Niedaleko zajedziecie, jak będziecie drukować jego prace stare w nowych zestawieniach. Bardzo natomiast jestem ciekawy Twej pracy o Gallus, bo ta kombinacja nie przyszła mi do głowy, ale nie znając Twoich argumentów, nie mogę zabierać a priori głosu w tej materii.

Gdybyście, Drodzy Państwo, wybierali się gdzieś w nasze strony na wypoczynek, to wstąpcie do nas, bardzo się będziemy cieszyć. Wiśka ma urlop dopiero w sierpniu, ale i tak spędzać go będziemy najprawdopodobniej w Krakowie, co najwyżej wyskakując na parę dni w moje rodzinne strony.

Kończąc, łączę od Wiśki i siebie mnóstwo serdeczności dla całej Familii i ściskam serdecznie prawicę Twoją

Karol

${ }^{1}$ Bogusław Leśnodorski (1914-1985), historyk państwa i prawa, pracownik Uniwersytetu Jagiellońskiego (1936-1949), Uniwersytetu Warszawskiego (od 1950), w l. 1953-1956 zastępca dyrektora Instytutu Historii PAN. ${ }^{2}$ K. Buczek, Ksiażęca ludność stużebna w Polsce wczesnofeudalnej, Wroctaw 1958. ${ }^{3}$ K. Kolańczyk, Osady stużebne w Polsce piastowskiej, Sprawozdania PAU 51, 1950, nr 6, s. 365-368. ${ }^{4} \mathrm{~K}$. Tymieniecki, Organizacja rzemiosła wczesnośredniowiecznego a geneza miast polskich, Studia Wczesnośredniowieczne 3, 1955, s. 9-98. ${ }^{5}$ G. Labuda, Źródta historiograficzne kroniki Anonima Galla, Sprawozdania PTPN 1955, nr 1, s. 21-22.

5

Or.: Wejherowo, MPiMKP, zbiory G. Labudy, karton 18, teczka 2, nlb. (rękopis)

Kochany Gerardzie,

Kraków, 10 listopada 1955

byłeś jednym z pierwszych, do którego pisałem po powrocie z Rawicza, nie mogę też oprzeć się chęci zawiadomienia Cię o moim powrocie do Rawicza, który nastąpi za 4 dni, wobec tego, że moja prośba o darowanie mi reszty kary została załatwiona negatywnie, o czym uwiadomiono mnie wczoraj. Wiśka pojechała zaraz do Warszawy, ale nie ma szans uzyskania przedłużenia przerwy kary. Ja sam starań dodatkowych nie robiłem, oprócz napisania paru listów (m.in. do H. Jabłońskiego') z dołączeniem kopii podania, sądziłem bowiem, że zdoła się ono obronić samo, zwłaszcza że według opinii miarodajnych osobistości odsiedziałem już swoje. Nie miałem zresztą do kogo się zwracać wobec dość powszechnego u kolegów po fachu braku zainteresowania moimi losami, tak w ciągu ubiegłych 8 lat, jak i w roku bieżącym. Trudno, trzeba pogodzić się jakoś nawet z przekreśleniem reszty życia i „kariery” naukowej. Tej ostatniej żałuję najmniej, bo do jej braku zdążyłem się przyzwyczaić; strasznie mi natomiast żal Wiśki, dla której rozpoczyna się nowy i niewątpliwie jeszcze trudniejszy odcinek Golgoty. Zrobiłbyś dobry uczynek, gdybyś zechciał czasem napisać do Niej parę słów, nawet nie licząc na wzajemność, bo do pisania to Ona jest bardzo ciężka. I jeszcze jedno. Gdyby się wyłaniały jakieś pomysły na temat pracy 
naukowej dla mnie z więzienia, to staraj się je z miejsca przeciąć; po tej lekcji nie wydusiłbym z siebie ani jednej rozsądnej myśli, ani nie sklecił paru choćby zdań. Nie miałoby to tym bardziej sensu, że w podaniu opisałem swoje prace w ciągu tego roku, a jest ich tyle, że wystarczyłoby dla kilku co najmniej historyków, rezultat zaś wiadomy.

Kończąc, dziękuję Ci serdecznie za okazaną mi przyjaźń i życzliwość, ręce całuję Twojej Pani, pozdrawiam Wszystkie Pociechy, żałując, że ich nie mogłem poznać, a Ciebie ściskam i całuję zapewne już po raz ostatni

Szczerze oddany

Karol

${ }^{1}$ Henryk Jabłoński (1909-2003), historyk, pracownik IH UW (od 1948), sekretarz naukowy PAN (1955-1965), wiceprezes PAN (1966-1971), poset na Sejm (1952-1989), przewodniczacy Rady Państwa PRL (1972-1985), członek KC PZPR (1948-1981, 1986-1990), członek Biura Politycznego KC PZPR (1971-1981), Minister Szkolnictwa Wyższego względnie Oświaty i Szkolnictwa Wyższego (1965-1972).

Or.: Wejherowo, MPiMKP, zbiory G. Labudy, karton 18, teczka 2, nlb. (rękopis).

Kraków, 23 listopada 1955

Kochany Gerardzie,

ponieważ Ci zakłóciłem spokój swoim pożegnalnym listem, zatem poczuwam się do obowiązku donieść $\mathrm{Ci}$, że przedwczoraj otrzymałem przedłużenie „urlopu” na 4 miesiące, w ciągu których sprawa moja ma być podobnie załatwiana w jakiś sposób ${ }^{1}$. Do Rawicza koniec końcem nie pojechałem, gdyż na 24 godziny przed wyjazdem dowiedziałem się całkiem przypadkiem, że nie popełnię żadnego przestępstwa, czekając na miejscu na „zaproszenie” przez prokuratora. Ponieważ zaś Wiśka zareagowała sercem na perspektywę rozłąki, zatem zdecydowałem się czekać w Krakowie na to „zaproszenie”, choć porobiłem już wcześniej wszelkie zakupy i przygotowania do odjazdu, wysłałem nawet odpowiedni telegram do Baśki², a przede wszystkim zdemontowałem gruntownie swój warsztat. Gdyby nie wzgląd na Wiśkę, to bym wrócił na stare „śmieci” nawet bez większych oporów, po pierwsze bowiem cenię sobie bardzo wysoko praworządność, po wtóre zaś nie bardzo widzę możliwość normalnej, twórczej pracy, skoro tak efektowna i efektywna jak ta ,urlopowa", skwitowana została kopniakiem przez władzę, a ponurym milczeniem przez miarodajną administrację naukową. Wiem, co mi na to odpowiesz („obecny etap" itd.), ale mnie to i tak nie przekona, bo jak wykazano choćby w ostatnich dyskusjach kulturologiczno-naukowych, racja jest, była i będzie po mojej stronie. Co prawda nie wiesz, jak wyglądało moje podanie, że było to nie tylko sprawozdanie z pracy naukowej, ale i kawałek traktatu naukowego na jeden arcyważny, kluczowy temat. Pisałem to podanie 2 września, a późniejsza dyskusja w Przeglądzie Kulturalnym i Nowej Kulturze dowiodła, że nie tylko mam rację, ale że tylko na tej drodze można wyjść z zaczarowanego koła, w którym różni autorzy gonią jak koty, usiłujące złapać swój ogon. Oczywiście bez najmniejszego powodzenia. 
Kończąc tę epistołę, łączę od Wiśki i siebie mnóstwo serdeczności dla Twojej Familii, Pani ręce całuję, a Tobie dłoń ściskam

Karol

${ }^{1}$ Wojewódzki Sąd Garnizonowy w Krakowie wystawit 18 XI 1955 r. postanowienie o przedtużeniu urlopu zdrowotnego K. Buczka o cztery miesiace. ${ }^{2}$ Barbara Raczkowska z domu Buczek (1925-1994), córka Karola i Jadwigi, chemik, w 1947 r. uciekła potajemnie na Zachód, mieszkała w Anglii, a później - do śmierci - w Stanach Zjednoczonych.

Or.: Wejherowo, MPiMKP, zbiory G. Labudy, karton 18, teczka 2, nlb. (rękopis).

Kochany Gerardzie,

Kraków, [koniec czerwca 1956]

żałuję żeśmy się nie spiknęli w Warszawie, ale ja byłem tam tylko przelotem i miałem bardzo mało czasu, a i Ty pewnie byłeś mocno zajęty. Zjawiłem się w Stolicy dlatego, że przed tygodniem otrzymałem z Rady Państwa wiadomość o definitywnym w zasadzie załatwieniu mej sprawy ${ }^{1}$, chciałem zatem dowiedzieć się, jak wyglądają moje szanse na etat w PAN-ie. Okazuje się, że na razie przynajmniej nienadzwyczajnie, wprawdzie bowiem dyrekcje Instytutów Geografii i Historii [PAN] reflektują na współpracę moją, ale na razie nie mają wolnych etatów, poza tym twierdzą, że muszę zaczynać od zastępcy profesora. Jakkolwiek to jest bardzo niewiele, to jednak będę musiał przystać i na to; gorsze, że nie mam najmniejszej pewności, czy nie będą chcieli na tym mnie zostawić, jak to zrobiono z M. Łodyńskim, nie mówić o wielu pomniejszych. Powiesz pewnie, że mam manię prześladowczą; istotnie do optymistów bym się sam nie zaliczył, ale też rozmowy z dyrektorami wymienionych wyżej instytutów oraz inne fakty do optymizmu absolutnie nie zachęcają. Myślę, że gdybym nie był tak wyspecjalizowany, a w związku z tym niezbędny, to przy mojej postawie pewnie bym musiał zrezygnować z pracy naukowej.

Tak czy owak zaczynać muszę „karierę” naukową właściwie od początku; mam na myśli wywalczenie sobie odpowiedniej pozycji. O ile się mogłem zorientować, to nie ma co myśleć o wydawaniu jakiejś większej pracy (książki), o ile oczywiście nie chodzi o taką rzecz, jak Monumenta Poloniae Cartographica ${ }^{2}$ itp., gdyż mógłbym czekać na to i parę lat. Zwłaszcza jeśli chodzi o robotę naprawdę porządną i nowatorską, w tym sensie, że burzy utarte schematy myślowe i autorytety. W tym stanie rzeczy postanowiłem iść na publikowanie prac drobnych w naszych [czasopismach] naukowych, a więc na sui generis czy też typowe przyczynkarstwo, wykorzystując swój dorobek powięzienny i więzienny. Wołałbym - rzecz jasna - robić swój okres (w. X-XIII) hurtem, a nie detalem, ale o tym, jak widzę, nie można marzyć, rzecz taka nie jest przewidziana w planie, a ja manną niebieską żyć nie potrafię. Zwłaszcza, że nie ma sensu pisać książek do biurka. A zgodzisz się chyba z tym, że publikować powinienem jak najwięcej. Chciałbym Cię zatem prosić, Mój Kochany, o pomoc w tym zakresie, zwłaszcza (ale niekoniecznie tylko) na terenie Poznania i w ogóle tych czasopism i wydawnictw periodycznych, w których masz coś do powiedzenia. Myślę przede wszystkim o Rocznikach Historycznych, Rocznikach 
Dziejów Społecznych i Gospodarczych oraz Studiach Wczesnohistorycznych [recte: Wczesnośredniowiecznych]. Pewnie jesteś doskonale zorientowany co do terminów ich ukazania się i szans zamieszczenia w nich rozpraw, zatem będziesz mnie mógł szybko poinformować bez żadnego dla siebie trudu. Tematów mam moc i różnych z wymienionego wyżej okresu, przede wszystkim społeczno-gospodarczych, a także i źródłoznawczych (główny nacisk na interpretacji), wiesz, że staram się dawać zawsze coś istotnie nowego i stojącego na możliwym poziomie. Nie potrzebuję Ci opisywać szeroko, jak wielką mi oddasz przysługę, dopomagając w tej materii, i jak bardzo Ci będę wdzięczny za wszelką w tym zakresie pomoc.

U nas poza tym wszystko po staremu. Wiśka męczy się w biurze i czuje nienadzwyczajnie, myślę też poruczyć jej funkcję zaopatrzeniowca po otrzymaniu przeze mnie jakiegoś etatu. Na wakacje nigdzie się nie wybierzemy, raz z braku forsy, po wtóre dlatego, że jednak muszę ciągle robić, skoro zaczynam wszystko od nowa i skoro nie należę do uprzywilejowanych. Gdyby nie to, że mam Wiśkę i chcę ją wyzwolić z niewoli biurowej, to bym najchętniej rzucił całą historię i wziął się do jakiejś „uczciwej” a spokojnej, a więc biurokratycznej roboty.

Przesyłam od Wiśki i od siebie dla Całej Waszej Familii mnóstwo wszelakich serdeczności, a Ciebie ściskam i całuję

Karol

${ }^{1}$ Rada Państwa zawiesiła 15 VI 1956 r. wykonywanie reszty kary więzienia K. Buczka na dwa lata. ${ }^{2}$ Byto to zaplanowane przed wojna wydawnictwo, publikujace dawne mapy. K. Buczek przygotowat zeszyt pierwszy, jednak nie zostat on opublikowany, w 1939 r. Niemcy bowiem zniszczyli spoczywajacy $w$ drukarni prawie cały nakład ksiązki.

\section{8}

Or.: Wejherowo, MPiMKP, zbiory G. Labudy, karton 18, teczka 2, nlb. (rękopis).

Kochany Gerardzie,

Kraków, [początek lipca 1956]

wybacz, że na Twoje urzędowe pismo - jako wicedyrektora Instytutu Zachodniego - odpowiadam prywatnie, chciałbym $\mathrm{Ci}$ jednak wytłumaczyć, dlaczego nie mam ochoty skorzystać z Twojej oferty, za którą Ci serdecznie i szczerze dziękuję, jako za dowód przyjacielskiej życzliwości i pomocy. Powody, które skłaniają mię do zrezygnowania z tejże, są dwojakiego rodzaju. Po pierwsze, nie pociąga mię, a nawet odstrasza, sam temat ze względu na jego rozległe ramy terytorialne i chronologiczne, a ściśle biorąc, również i rzeczowe, oraz - w związku z tym - jego wybitnie sprawozdawczy z konieczności charakter. Mnie kolonizacja na prawie niemieckim bardzo interesuje siłą rzeczy, mało mnie natomiast interesuje to, co dotychczas na ten temat pisano. Oczywiście, wszystko co ważniejsze, trzeba znać, ale powtarzać tego nie mam ochoty z tego przede wszystkim względu, że ja na te rzeczy, jak i na bardzo wiele innych, patrzę $z$ odmiennego metodologicznie punktu widzenia. Osobiście jestem zdania, że trzeba opracowywać zagadnienie od nowa, nie warto natomiast grzebać się w tej całej starzyźnie. Poza tym nie sądzę, by można było nad tak szeroko zakrojonym tematem pracować efektywnie poza Poznaniem. Przekonałem 
się o tym, pisząc swoje „Geograficzno-historyczne podstawy Prus Wschodnich", pół energii bowiem włożonej w tę również ,zadaną” pracę zużyłem na zdobywanie niedostępnych w Krakowie książek.

Po wtóre, trudno byłoby mi obecnie znaleźć czas na tę wymagającą masy czasu robotę. Jak Ci to przed paru dniami pisałem, zaczynać muszę swoją naukową (w sensie stopnia służbowego) karierę niemal od początku. Znajduję się zaś w sytuacji bardzo trudnej, gdyż masę czasu zajmują mi zajęcia gospodarcze - Wiśka nieprędko [... - tekst urwany] urwać z biura, nie prędzej w każdym razie aż ja [będę pracował] w którymś z Instytutów, a poza tym czuję się coraz słabszy fizycznie (przydałby mi się jakiś generalny remont - wypoczynek), a i psychicznie czuję się bez porównania gorzej, niż pod koniec 1954 r. Tak mi długo podskubywano skrzydełka, aż mi je wyskubano z piórek zapału. Koniec końców sprawy stoją w ten sposób, że mam umowę z Komitetem Historii Nauk[i] na opracowanie części I tomu Monumenta Poloniae Cartographica jeszcze w tym roku, przypuszczalnie będę pracował dalej nad tą publikacją na etacie Instytutu Geografii [PAN], gdyż Manteuffel nie ma zamiaru zaangażować mnie na stałe do $\mathrm{IH}[\mathrm{PAN}]^{2}$. Poza tym powinien bym napisać rozprawę do księgi Miechowity, która ma się ukazać w przyszłym roku na 500-lecie jego urodzin, bo nikt tego uczciwie nie zrobi ${ }^{3}$. No i wreszcie, chciałbym uaktywnić swoje nazwisko na niwie historiografii, a to też wymagać będzie trochę czasu. W tym stanie rzeczy nie mogę brać na siebie z czystym sumieniem tak pracochłonnego tematu, jak ten zaproponowany przez Ciebie, a jeszcze tak nieefektowny i nieefektywny.

Myślę, że po tym, co powiedziałem, nie weźmiesz mi za złe mojej odmowy i ze swojej strony nie odmówisz mi swej pomocy zarówno w wypuszczeniu na światło dzienne moich prac, jak także przy planowaniu jakichś innych robót dla Instytutu Zachodniego czy innego. Przypuszczam, że w bezpośredniej dyskusji potrafiłbym Ci to wyłożyć lepiej i przekonać Cię, cóż jeśli nie chcesz zjawić się w Krakowie i na wakacje pewnie wybierzecie się Państwo nad morze. Ogromnie niepokoimy się z Wiśką stanem zdrowia Pani Alby i myślę, że coś się dowiemy o tym. My w każdym razie nigdzie się $\mathrm{z}$ domu nie ruszamy.

Raz jeszcze dziękuję Ci serdecznie za próbę przyjacielskiej pomocy oraz łączę od Wiśki i siebie najlepsze życzenia przyjemnych wakacji oraz serdeczne pozdrowienia dla Twojej Rodziny.

Mocno dłoń ściskam Karol

\footnotetext{
${ }^{1}$ K. Buczek, Geograficzno-historyczne podstawy Prus Wschodnich, w: Dzieje Prus Wschodnich, Toruń 1936. ${ }^{2}$ K. Buczek zostat zatrudniony w Instytucie Historii PAN w grudniu 1956 r. na etacie zastępcy profesora. Nominacje na profesora nadzwyczajnego uzyskat 1 II $1957 \mathrm{r}$. W Instytucie Historii PAN organizowat Pracownie Stownika Historyczno-Geograficznego Polski Średniowiecznej. ${ }^{3}$ K. Buczek, Maciej z Miechowa jako geograf Europy Wschodniej, w: Maciej z Miechowa 1457-1523. Historyk, geograf, lekarz i organizator nauki, Wroctaw-Warszawa 1960, s. 75-166.
} 
Or.: Wejherowo, MPiMKP, zbiory G. Labudy, karton 18, teczka 2, nlb. (rękopis).

Kochany Gerardzie,

Kraków, [początek lipca 1956]

nie uwierzysz mi może, bo ja sam w to nie bardzo mogłem uwierzyć, [ale nie] mam ani jednego egzemplarza „Biblioteki Puławskiej” w czasie powstania listopadowego ${ }^{1}$. Nie mam nawet pojęcia, jak to się stało, bo na ogół dbałem o to, żeby mieć choć jeden egzemplarz swoich prac, ale na tę jakoś całkowicie nie zwróciłem uwagi, bo - inna rzecz - że sprawy te całkiem mnie już nie interesują i nawet nie lubię chodzić do tego, co dziś się nazywa Biblioteką Czartoryskich. Myślę jednak, że Biblioteka Kórnicka powinna posiadać, jeśli nie odbitkę, to komplet „Silva Rerum”, gdzie się to drukowało. Bardzo mi przykro, że nie mogę spełnić Twojej prośby, ale akurat tak się to musiało pechowo złożyć.

U mnie wszystko po staremu. O sprawie etatu nic nie wiem i biorąc pod uwage pewne fakty, zaczynam powątpiewać, czy w ogóle takowy dostanę. Gdzie jak gdzie, ale w naszej nauce i jej organizacji to nic się - oczywiście na lepsze - nie zmieniło. W każdym razie postanowiłem zażyć na cierpliwość i czekać. W najgorszym razie będę prowadził dalej gospodarstwo domowe, choć większy by miało sens, gdyby to robiła Wiśka. Ale sens to u nas niemile widziany gość, toteż im dłużej siedzę na „wolności”, tym bardziej mile wspominam lata spędzone na Waszej ziemi w R[awiczu] i W[ronkach]. Oddałem już do druku „łagiewników” i przygotowałem „stróżów” (studium z ustroju społecznego Polski wczesnofeudalnej) dla Roczników Dziejów Społecznych i Gospodarczych ${ }^{2}$. Nb. musisz mnie zaprotegować u Rusińskiego ${ }^{3}$, żeby to szybko wydrukowali, w przeciwnym razie zresztą tego im nie dam. Jak tylko Wiśka urwie się na urlop, to mi to przepisze na maszynie. Napisałem również rzecz pt. „W sprawie interpretacji dokumentu trzebnickiego z 1204 r.” (2-3 arkusze) ${ }^{4}$, a teraz męczę się nad prawem rycerskim, bo chcę to skończyć i wrócić do historii kartografii.

Na wakacje z braku czasu i forsy oczywiście nie wyjedziemy, choć bardzo by nam się przydały. Na zakończenie przesyłamy oboje z Wiśką dla Kochanych Państwa mnóstwo wszelakich serdeczności.

Ściskam prawicę

Karol

\footnotetext{
${ }^{1}$ K. Buczek, Biblioteka Puławska w czasie walk powstania listopadowego, Silva Rerum 10-12, 1930, s. 163-165. ${ }^{2}$ Tenże, Stróże - studium z ustroju społecznego Polski wczesnofeudalnej, Roczniki Dziejów Społecznych i Gospodarczych 19, 1957, s. 11-43. ${ }^{3}$ Władysław Rusiński (1911-1986), historyk, pracownik Uniwersytetu Poznańskiego i UAM (1937-1962), Wyższej Szkoły Ekonomicznej w Poznaniu (od 1962), redaktor Roczników Dziejów Społecznych i Gospodarczych (1953-1986). ${ }^{4}$ K. Buczek, W sprawie interpretacji dokumentu trzebnickiego z r. 1204, Przeglad Historyczny 48, 1957, z. 1, s. 38-77.
} 
Or.: Kraków, Biblioteka Naukowa Polskiej Akademii Umiejętności i Polskiej Akademii Nauk, rkp 10586, nlb. (maszynopis).

Kochany Karolu!

[Poznań], 11 lipca 1956

dziękuję Ci za dwa ostatnie listy, wyjaśniające Twój stosunek do zaoferowanych prac zleconych. Oczywiście, w zupełności podzielam Twój pogląd. Była to zresztą tylko reakcja na Twój poprzedni list. Na szczęście, tymczasem sprawy Twoje w zupełności się wyjaśniły, z czego ogromnie się z żoną cieszymy.

$\mathrm{Na}$ Twoim miejscu zdecydowałbym się raczej na etat w Instytucie Geograficznym, który mimo wszystko wydaje mi się poważniejszy od naszego. Przy tym obecnym składzie naukowym Dyrekcji [Instytutu Historii PAN], która nie posiada jakiejś bardziej twórczej koncepcji, poza mechanicznymi odruchami, nie sądzę, ażeby przez wiele jeszcze lat udało się w nim ożywić tętno życia naukowego i dyskusji. Nasz Instytut wybiera się na polowanie na z góry upatrzonego zwierza, który nb. jest przywiązany za nogę. Nie lubi więc ryzyka, polemiki, odmiennego zdania.

$\mathrm{W}$ tej chwili w modzie jest publikowanie wyników swoich prac w formie artykułów, szkiców, rozprawek i przyczynków. Jasne. Marksistowska synteza jest rzeczą niezwykle trudną. Gdy się pisze artykuł, człowiek od razu triumfuje nad 50\% przeciwników. Wszystkie braki załatwia się hurtem w jednym odsyłaczu. To dopiero będzie!

Zapewne i Ty musisz próbować tego samego. Rozmawiałem z Rusińskim (Poznań, Kościuszki 101, róg Libelta), który chętnie przyjmie do Roczników Dziejów Społeczno-Gospodarczych artykuł z Twego zakresu zainteresowań. Może byś podał kilka przypuszczalnych tytułów. Na pewno potrafiłbym upchać stosunkowo szybko kilka dalszych. Ale na jedno musisz być z góry przygotowany. Tzw. cykl produkcyjny trwa $\mathrm{z}$ reguły dwa lata. Na to nie ma rady. No po prostu nikt nie jest w stanie na to poradzić. Jedyny Przegląd Zachodni drukował szybciej. Ale ten nie miał takich skrupułów redaktorskich, jakie mają organy naukowe. Może z czasem pozbędziemy się tej przywary, ale chyba nie tak szybko. Ja, będąc redaktorem jednego z czasopism, czekam już trzeci rok ${ }^{1}$. W międzyczasie wiele się zmieniło. To i owo trzeba by napisać inaczej (gdyż rzecz jest z dziedziny metodyki historii), na niektóre rzeczy człowiek po tylu miesiącach patrzy inaczej. Jednym słowem, nie ma tego złego, co by na dobre nie wyszło.

Jestem przekonany, że Ty na początku będziesz się nieco irytował. Ale potem przywykniesz i zaczniesz wynajdywać dobre strony. Dobre strony złej konieczności.

W tym roku również nie wybierzemy się na żadne dalsze eskapady. Albusia wyjechała z dziećmi niedaleko pod Poznań. Właśnie za chwilę wybieram się tam rowerem. Ja będę pewnie większość wakacji przesiadywał w samym Poznaniu, pilnując budowy domu i odrabiając ciągłe zaległości (podręcznik jednak zabrał prawie dwa lata $^{2}$, nie licząc roku choroby). Pomyśleć, że ciągle nie mogę z siebie zrzucić prac zapoczątkowanych na pierwszym roku studiów. Chciałbym już odejść od wyczynów z zakresu metody filologicznej i przejść do historii. Ale kiedy to nastąpi?

Łączę najmilsze pozdrowienia od żony i od siebie; jeszcze raz manifestuję naszą radość z Twego powrotu do życia cywilnego, do nauki 
${ }^{1}$ Najpewniej chodzi o artykut: Próba nowej systematyki i nowej interpretacji źródet historycznych, Studia Źródłoznawcze 1, 1957, s. 3-52. ${ }^{2}$ Mowa o udziale autorskim w Historii Polski, przygotowywanej w Instytucie Historii PAN pod red. H. Lowmiańskiego. G. Labuda napisat (samodzielnie albo we wspótpracy) kilka rozdziałów.

\title{
BIBLIOGRAFIA
}

Biliński P., „Przypadek” Karola Buczka, Arcana 46-47, 2003.

Buczek K., Autobiografia mediewisty-polityka, wyd. J. Dużyk, Studia Historyczne 35, 1992.

Dąbrowski F., Pięć listów Karola Buczka do władz komunistycznej Polski, Kwartalnik Historii Kultury Materialnej 56, 2008.

Karol Buczek (1902-1983). Człowiek i uczony, red. D. Karczewski, J. Maciejewski, Z. Zyglewski, Kraków-Bydgoszcz 2004.

Musiał F., Polityka czy sprawiedliwość. Wojskowy Sąd Rejonowy w Krakowie (1946-1955), Kraków 2005.

Naukowe dzieło Profesora Gerarda Labudy, red. J. Dobosz, Poznań 2006.

Pro memoria. Gerard Labuda (1916-2010), wyd. J. Borzyszkowski, Gdańsk-Wejherowo 2011.

Sikora F., O życiu i działalności Karola Buczka, w: K. Buczek, Studia z dziejów ustroju społeczno-gospodarczego Polski piastowskiej, t. I, Kraków 2006.

Strzelczyk J., Gerard Labuda 1916-2010, Roczniki Historyczne 76, 2010.

\section{A difficult life at large. The correspondence of Karol Buczek with Gerard Labuda from the years 1954-1956}

\author{
Summary
}

The historian Karol Buczek from Cracow was in prison from 1946. His arrest was connected with the fight of communists with the opposition, especially the Polish People's Party, of which Buczek was an activist. In November of 1954 Buczek was granted a year's leave, while in June of 1956 the Council of State suspended his imprisonment. During those two years Buczek corresponded with his friend from Poznań, the historian Gerard Labuda. The letters show, how difficult it was for Buczek to function in the first dozen or so months of being at large, when the threat of returning to prison was still real. They show the state of mind of the Cracow historian, his thoughts, worries and uncertainly about his future, as well as an attempt at returning to scholarly life. The letters may be an important contribution to understanding how a Polish intellectual (scholar) functioned in the first months of leaving a Stalinist prison. 